\title{
Gender Wise Perception Towards Teachers' Use of Motivational Strategies in Esl Classroom
}

\author{
L. Vidhya and K. Anbazhagan \\ Department of English and Foreign Languages, SRM Institute of Science \\ and Technology, SRM Nagar, Kattankulathur, Tamil Nadu, India
}

\section{ABSTRACT}

A key factor in the learning of ESL is motivation. Motivation plays an essential part in students' performance and achievement and since they look at the teacher to be their role model motivational factors in a teacher is to be concentrated much. This study aims to revisit students' perception especially with gender towards the teachers' use of strategies that motivate the learning of English language. The sample comprised of 58 students who travelled with the teacher for a period of one full semester and the responses provided by them about the strategies are explicitly pronounced. The data were collected through circulation of questionnaire posted through Google forms. The questionnaire comprised of 15 items, each question was fixed with a five-point likert scales ranging from strongly agree (5) to strongly disagree (1). The study is done with t-test analysis to find out whether there is a significant or there is no significant difference between genders of students towards teachers' use of motivational strategies. The study findings conclude that there is no statistically significant difference between the gender towards teachers' use of motivational strategies.

\section{KEY WORDS: MOTIVATION, PERCEPTION, MOTIVATIONAL STRATEGIES.}

\section{INTRODUCTION}

Motivation And Motivational Theories: Motivation is the key component that is looked at as the goal directed feature or behaviour according to many language researchers (Adelman \& Taylor, 1990). Teachers are regarded as people who induce and stimulate the growth of the learners and between the learners and the teachers' motivation play a critical role in the process of teaching and learning. In the process of learning it becomes easier when there is an urge and thirst to learn things especially with interest. That interest could be from within or from any external factor and here the external factor is the role of the teacher.

In the growth of human life learning is a fundamental process, successful learning happens through motivation. There are varied approached of teaching that encourages

Biosc Biotech Res Comm P-ISSN: 0974-6455 E-ISSN: 2321-4007

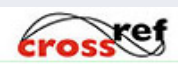

Identifiers and Pagination

Year: 2021 Vol: 14 No (8) Special Issue

Pages: 24-28

This is an open access article under Creative

Commons License Attribn 4.0 Intl (CC-BY). DOI: http://dx.doi.org/10.21786/bbrc/14.8.6 the learners to go deep in to learning of anything with personal comprehension. According to Biggs (1999) learning environment plays a major role in the motivational context to in depth learning. Motivation paves way to 'lifelong learning'. Schunk, 2000 has reported that defining motivation widely differs and that there exist diverse theories, interpretations and it is a complex component to describe. The learners may show difference in their adoption of strategies with reference to the use of teachers' motivational teaching strategies.

It is the Latin word movement that has given rise to the word motivation. Lewin (1938) reported that motivation is the act of acquiring something to benefit self in order to achieve a set goal. It is a determinant of thought and action. Motivational theories give us a vivid picture on the different dources of motivation and how it influences under four different psychological variables, they are behavioural, humanistic, cognitive and social learning and these having the sources of motivation with reinforcement of factors like extrinsic, intrinsic, intrinsic and both extrinsic, intrinsic reinforcements respectively influenced by operant behaviours like rewards, incentives, establishing self-esteem, selffulfilment and determination with beliefs, attributions for success and failure expectations and value of goals
Article Information

Received: $11^{\text {th }}$ Apr 2021 ccepted after revision: $18^{\text {th }}$ June 2021 
expectancy of reaching goals. This is derived from the earliest behavioural theories by Skinner.

Perception: According to Tynjala (1997) perception is defined as more than observation, thinking and much more than being aware of things by means of the senses. In the words of Struyven, Dochy and Janssens (2003), perception comprises of all acts through which people share the 'meaning' and the 'concept' to the surrounding world. Students can have perceptions towards the entire factors that concern their learning, especially the teachers presentation of material, topics relevance, text book prescribed, teachers providing of opportunities to students to express, how teacher addresses each individual in the classroom, the practice given to them for the topics that are handled, feedback provided, teachers behaviour, and so on.

Review of Literature: The vital factor that stimulates students' motivation is the teachers' motivation and the strategies that are adopted by them to influence the life long process of learning a language. It is true that only when a person is motivated that same amount of motivation can be shared with others if not nothing could really happen. It is simple that first a teacher should be highly motivated in order to motivate their students. Unmotivated or demotivated teachers' cannot raise or enhance the students' interest. Teachers are father figures who are if motivated and sustain with either the same level or an improved level can easily be identified with their approaches in their classrooms and such classrooms could be seen with positivity, warm-hearted and much active classroom where learning happens emphatically. According to Ames (1990) reviewed scholarly articles and highlighted that there are eight general instructional strategies prevailing in order to increase students' participation they are using extrinsic rewards, goal setting, encouraging social cooperation, developing students self- confidence and offering choice, developing circumstantial interest and championships.

It is believed that there is possibility in changing students' motivation in a positive direction and in order to achieve this possibility teachers' methodological repertoire plays a key role. To improve students' motivation, it is best suggested that teachers' behaviours and instructional practices play an important role ( Assor et al.,2005; Bernaus \&t Gardner,2008; Corpus, McClintic-Gilbert, Et Hayenga,2009; Dweek,2003; Gottfried, Fleming \&t Gottfried,2001; Jang, Kim, \& Reeve, 2012; Lai \& Ting,2013; Loima \&t Vibulphol, 2014,2016;Niemiec \&t Ryan,2009; Papi \&t Abdollahzadeh, 2011 ;Urhahne, 2015). In the words of Niemiec \& Ryan, 2009; Reeve, 2009 ,the students intrinsic motivation and lifelong learning is promoted by the teachers autonomy-support styles as it gives the sense of control over the task. According to Jang, Reeve and Deci (2010) the intrinsic motivation of students happened through much space given to them by the teachers for individual learning.

In the process of teaching and learning strategies play an inevitable role. According to Mehrgan, 2013 language teaching strategy is a set of pedagogical procedures imposing a definite learning strategy on the learners to develop the competence in the target language. Takac (2008) describes teaching strategy to be everything teachers do or should do in order to help the learners learn. Teachers use strategy depending on the time available, the material as well as its effect on the students. In the process of learning there is sync between the teachers' use of teaching strategy and students' motivation. Cheng and Dornyei, 2007 found if the teacher provides appropriate conditions or environment to learn and utilize motivational teaching strategies that motivated the learners to a greater extent. Thus, it is made clear that teachers have an inevitable role in the students' success in learning English as a second language. It is advised that teachers must adopt a suitable teaching strategy that best suits the students' which would make students' better understand the learning objectives and keep them highly motivated to learn the language.

Statement of the Problem: In the process of learning the second language to an ESL learner motivation is very important. The teacher as a facilitator should facilitate learning by implementing strategies that would help or better suit them (the learners) to have sustainability towards learning of English as a second language.

Aim and Objective of the Study: The study aims to find the gender wise perception towards teacher's use of motivational strategies. The study assesses whether there is any significant difference or no significant difference between the genders of students' towards their teacher's use of motivational strategies in the English classroom.

\section{Objectives:}

1. To find whether there is or there is no significant changes according to the gender of students to the strategies they were introduced to by the teacher in the English classroom.

2. To learn the strategies that were implemented by the teacher in arousing the motivation of the students.

\section{Hypotheses:}

Ho: There is no significant difference between the gender towards teachers' use of motivational strategies.

H1: There is significant difference between the gender towards teacher's use of motivational strategies

\section{Research Question:}

1. What is the gender wise perception of students towards the teachers' use of motivational strategies?

2. Whether those strategies adopted by the teacher made significant changes in the gender wise learning of the language?

\section{MATERIAL AND METHODS}

Participants: The data were collected using convenient sampling method from 58 students who took up English classes for one full semester of 30 hours 
( 2 credit programme). As approached the students showed willingness to participate in the study. With respect to gender 38 female students and 20 male students have participated in the study. The questionnaire consisted of socio-demographic variables like gender, mother tongue, and parents' occupation, mode of instruction at school and self assessment of their level of language efficiency. But this study particularly concentrates on gender and gender wise perception towards the teacher's use of motivational strategies in the classroom.

Table 1. Participants Response

\begin{tabular}{|c|c|c|c|c|c|c|c|c|c|c|}
\hline & \multicolumn{2}{|c|}{$\begin{array}{c}\text { Strongly } \\
\text { agree }\end{array}$} & \multicolumn{2}{|l|}{$\begin{array}{c}\text { Agree } \\
\text { (4) }\end{array}$} & \multicolumn{2}{|l|}{$\begin{array}{c}\text { Neutral } \\
\text { (3) }\end{array}$} & \multicolumn{2}{|l|}{$\begin{array}{l}\text { Disagree } \\
\text { (2) }\end{array}$} & \multicolumn{2}{|l|}{$\begin{array}{l}\text { Strongly } \\
\text { disagree } \\
\text { (1) }\end{array}$} \\
\hline & Female & Male & Female & Male & Female & Male & Female & $\underset{\text { e }}{\text { Mal }}$ & Female & Male \\
\hline Q1 & 29.3 & 15.5 & 32.8 & 19 & 3.4 & 0 & 0 & 0 & 0 & 0 \\
\hline Q2 & 20.7 & 17.2 & 36.2 & 13.8 & 8.6 & 3.4 & 0 & 0 & 0 & 0 \\
\hline Q3 & 12.1 & 12.1 & 22.4 & 8.6 & 19 & 6.9 & 12.1 & 6.9 & 0 & 0 \\
\hline $\mathrm{Q} 4$ & 37.9 & 22.4 & 22.4 & 8.6 & 5.2 & 3.4 & 0 & 0 & 0 & 0 \\
\hline Q5 & 19 & 19 & 34.5 & 12.1 & 10.3 & 1.7 & 1.7 & 1.7 & 0 & 0 \\
\hline Q6 & 25.9 & 15.5 & 34.5 & 17.2 & 1.7 & 1.7 & 3.4 & 0 & 0 & 0 \\
\hline Q7 & 34.5 & 20.7 & 27.6 & 12.1 & 3.4 & 17 & 0 & 0 & 0 & 0 \\
\hline Q8 & 25.9 & 24.1 & 32.8 & 8.6 & 6.9 & 1.7 & 0 & 0 & 0 & 0 \\
\hline Q9 & 19 & 17.2 & 43.1 & 13.8 & 3.4 & 3.4 & 0 & 0 & 0 & 0 \\
\hline Q10 & 39.7 & 17.2 & 25.9 & 13.8 & 0 & 3.4 & 0 & 0 & 0 & 0 \\
\hline Q11 & 22.4 & 15.5 & 43.1 & 19 & 0 & 0 & 0 & 0 & 0 & 0 \\
\hline Q12 & 25.9 & 10.3 & 31 & 19 & 8.6 & 5.2 & 0 & 0 & 0 & 0 \\
\hline Q13 & 27.6 & 13.8 & 32.8 & 20.7 & 5.2 & 0 & 0 & 0 & 0 & 0 \\
\hline Q14 & 19 & 13.8 & 37.9 & 20.7 & 8.6 & 0 & 0 & 0 & 0 & 0 \\
\hline Q15 & 31 & 17.2 & 29.3 & 17.2 & 5.2 & 0 & 0 & 0 & 0 & 0 \\
\hline
\end{tabular}

Table 2. Mean, Standard deviation, t-test, p-value

\begin{tabular}{|c|c|c|c|c|}
\hline Questions & Mean & SD & $\mathbf{t}$ & p-value \\
\hline $\begin{array}{l}\text { 1. The English teacher presents materials in an } \\
\text { interesting way }\end{array}$ & 4.41 & \pm 0.563 & 0.353 & 0.726 \\
\hline $\begin{array}{l}\text { 2. The teacher chooses topics that she thinks are } \\
\text { relevant to students' lives. }\end{array}$ & 4.26 & \pm 0.664 & 1.181 & 0.243 \\
\hline 3. The teacher does not always follow the text book. & 3.6 & \pm 1.059 & 0.762 & 0.449 \\
\hline $\begin{array}{l}\text { 4. The teacher gives everyone a turn to speak in order } \\
\text { to check students' understanding. }\end{array}$ & 4.52 & \pm 0.655 & 0.274 & 0.785 \\
\hline $\begin{array}{l}\text { 5. The teacher addresses questions to the whole class } \\
\text { rather than to selected individuals. }\end{array}$ & 4.19 & \pm 0.783 & 1.501 & 0.139 \\
\hline $\begin{array}{l}\text { 6. The teacher gives students enough time in class to } \\
\text { practise their English language. }\end{array}$ & 4.31 & \pm 0.706 & 0.698 & 0.488 \\
\hline 7. The teacher provides positive feedback. & 4.5 & \pm 0.6 & 0.457 & 0.649 \\
\hline $\begin{array}{l}\text { 8. The teacher adopts a friendly, non-authoritarian } \\
\text { manner. }\end{array}$ & 4.41 & \pm 0.65 & 2.065 & $\star 0.044$ \\
\hline $\begin{array}{l}\text { 9. It is better to receive feedback from my classmates } \\
\text { and teacher. }\end{array}$ & 4.29 & \pm 0.593 & 0.997 & 0.323 \\
\hline $\begin{array}{l}\text { 10. The teacher encourages students to have speaking } \\
\text { sessions in class. }\end{array}$ & 4.53 & \pm 0.569 & -1.315 & 0.194 \\
\hline $\begin{array}{l}\text { 11. The teacher gives students good reasons for why a } \\
\text { specific task is meaningful. }\end{array}$ & 4.38 & \pm 0.489 & 0.795 & 0.43 \\
\hline $\begin{array}{l}\text { 12. The teacher creates a supportive classroom } \\
\text { environment so students would take risks. }\end{array}$ & 4.22 & \pm 0.677 & -0.602 & 0.55 \\
\hline $\begin{array}{l}\text { 13. The teacher allows students to choose topics for } \\
\text { conversation and videos for discussion. }\end{array}$ & 4.36 & \pm 0.583 & 0.356 & 0.723 \\
\hline $\begin{array}{l}\text { 14. The teacher supplements the students' text book } \\
\text { with visual materials from the internet. }\end{array}$ & 4.24 & \pm 0.601 & 1.472 & 0.147 \\
\hline $\begin{array}{l}\text { 15. The teacher monitors students progress and } \\
\text { celebrates their victories. }\end{array}$ & 4.43 & \pm 0.596 & 0.636 & 0.527 \\
\hline
\end{tabular}

Method: The study has adopted a mixed-method design, which focuses on both the qualitative and the quantitative data. The study gives a descriptive statistical analysis of the data collected. The data obtained were analysed using SPSS 3.6.
Instrument: The questionnaire was adopted from Elashhab , S. (2020). Motivational Teaching Strategies within Saudi University EFL Classrooms: How to Improve Students' Achievement?. International Journal of Language and Literary Studies, 2(1), 124-141. https:// doi.org/10.36892/ijlls.v2i1.173. The questionnaire was 
circulated through google form through mail to 58 first year students of Physiotherapy who took up English as an elective paper under CBCS Programme of a medical university. The questions are focusing on getting the data about their views on the motivational strategies used by the teacher in order to improve their language learning achievement. Results and discussion: The collected data is inferred in the tables that follow.

Table 1: Distribution of the percentage with respect to gender wise perception of the questions number Q1Q15 with likert scale ranging from strongly agree (5) to strongly disagree (1). The questions are as follows:

1. The English teacher presents materials in an interesting way.

2. The teacher chooses topics that she thinks are relevant to students' lives.

3. The teacher does not always follow the text book.

4. The teacher gives everyone a turn to speak in order to check students' understanding.

5. The teacher addresses questions to the whole class rather than to selected individuals.

6. The teacher gives students enough time in class to practise their English language.

7. The teacher provides positive feedback.

8. The teacher adopts a friendly, on-authoritarian manner.

9. It is better to receive feedback from my classmates and teacher.

10. The teacher encourages students to have speaking sessions in class.

11. The teacher gives students good reasons for why a specific task is meaningful.

12. The teacher creates a supportive classroom environment so students would take risks.

13. The teacher allows students to choose topics for conversation and videos for discussion.

14. The teacher supplements the students' text book with visual materials from the internet.

15. The teacher monitors students' progress and celebrates their victories.

Table 2 indicates that there is no statistically significant difference at $\mathrm{p} \leq 0.05$ between the genders and the acknowledgement to questions is the same, but to one variable alone there is a significant difference in the $p$ value that is to q8 "the teacher adopts a friendly, non authoritarian manner" with $\mathrm{p}$ value of 0.044 which is statistically significant at $p \leq 0.05$. Thus, it is found that there is no difference between the genders in perception towards the teacher's use of motivational strategies. The similar set of questions used by Elashhab, S. showed that of the 100 students from whom the data were collected to question 8,68 students strongly agreed that the teachers manner supported their learning and 32 expressed their neutrality towards teachers being non-authoritarian and friendly in approach.

\section{CONCLUSION}

In the process of learning a second language both external and internal factors have its role, undoubtedly, motivation ranks high among the external factors. Strategies are effective implements to stimulate the participation of the students. It is good to have a learner- centered and goal -oriented atmosphere. According to Dornyei, 2001:28 it is reported that strategies are techniques promoting an individual's goal-centered performance. Teachers possessing power have liberality to create dynamic materials to energise the motivated and re-energise the demotivated students'. Successful teachers' adopt strategies and prepare well concentrating on the participation of their students. To conclude, teachers' are to be motivated first in order to motivate their learners, without sufficient motivation and implication of suitable strategies even individuals possessing an exceptional ability could not continue learning for a longer period of time.

\section{ACKNOWLEDGEMENTS}

I thank the almighty to have given me abundant grace in completing the research paper. I am much obliged to thank my guide DR. K. Anbazhagan for being a constant support in completion of the research paper with his suggestions and guidance. My deep sense of gratitude to the study participants, 58 undergraduate Physiotherapy students of SRIHER (DU) and the statistician Mrs. A.Nirmaladevi, Lecturer in Computer Science,SRIHER (DU) to help with the data analysis.

\section{REFERENCES}

Adelman HS, Taylor L. Intrinsic motivation and school misbehavior: some intervention implications. J Learn Disabil. 1990 Nov;23(9):541-50. doi: 10.1177/002221949002300903. PMID: 2250134.

Ames, C. ( 1990, April). The relationship of achievement goals to student motivation in classroom settings. Paper presented at the annual meeting of the American Educational Research Association, Boston, MA. [Google Scholar]

Assor, A., Kaplan, H., Kanat-Maymon, Y., \&t Roth, G. (2005). Directly controlling teacher behaviors as predictors of poor motivation and engagement in girls and boys: The role of anger and anxiety. Learning and Instruction, 15, 397-413. http://dx.doi.org/10.1016/j. learninstruc.2005.07.008

Bernaus, M., \&t Gardner, R. (2008). Teacher motivational strategies, student perceptions, student motivation, and English achievement. The Modern Language Journal, 92(3), 387-401. http://dx.doi.org/10.1111/j.15404781.2008.00753.x

Biggs, J. (1999). Teaching for Quality Learning at University. SHRE and Open University Press.

Cheng, H., and Dörnyei, Z. 2007. The Use of Motivational Strategies in Language Instruction: The Case of EFL Teaching in Taiwan. Innovation in Language Learning and Teaching,Volume 1 Number 1, 153- 174.

Classrooms: How to Improve Students' Achievement?. International Journal of Language and Literary Studies, 
2(1), 124-141. https://doi.org/10.36892/ijlls.v2i1.173. The Gottfried, A. E., Fleming, J. S., \&t Gottfried, A. W. (2001). Continuity of academic intrinsic motivation from childhood through late adolescence: A longitudinal study. Journal of Educational Psychology, 93(1), 3-13. http://dx.doi.org/10.1037/0022-0663.93.1.3

Corpus, J. H., McClintic-Gilbert, M. S., \& Hayenga, A. 0. (2009). Within-year changes in children's intrinsic and extrinsic motivational orientations: Contextual predictors and academic outcomes. Contemporary Educational Psychology, 34, 154-166. http://dx.doi. org/10.1016/j.cedpsych.2009.01.001

Dörnyei, Z. and M.J. Guilloteaux (2008). Motivating language learners. A classroomoriented investigation of the effects of motivational strategies on student motivation. TESOL Quarterly, 42 (1), 55-77.

Dweck, C. S. (2002). Messages that motivate: How praise molds students' beliefs, motivation, and performance (in Surprising Ways). In A. Joshua (Ed.) Improving academic achievement: Impact of psychological factors on education (pp. 38-58). New York, NY: Academic Press. http://dx.doi.org/10.1016/B978-0120644551/50006-3 Elashhab , S. . (2020). Motivational Teaching Strategies within Saudi University EFL

English Language Teaching, 6(8), 10-20. http://dx.doi. org/10.5539/elt.v6n8p10

Jang, H., Reeve, J., \&t Deci, E. L. (2010). Engaging students in learning activities: It is not autonomy support or structure but autonomy support and structure. American Psychological Association,102(3), 588-600. http://dx.doi.org/10.1037/a0019682

Jang, H., Kim, E. J., \& Reeve, J. (2012). Longitudinal test of self-determination theory's motivation mediation model in a naturally occurring classroom context. Journal of Education Psychology, 104, 1175-1188. http://dx.doi.org/10.1037/a0028089

Lai, H. T., \&t Ting, K. (2013). English language learners' perception on motivational changes.

Lewin, K.; Lippitt, R.; White, R.K. (1938). "Patterns of aggressive behavior in experimentally created social climates”. Journal of Social Psychology. 10 (2): 271299
Loima, J., \&t Vibulphol, J. (2014). Internal interest or external performing? A Qualitative study on motivation and learning of 9th graders in Thailand basic education. Journal of Education and Learning, 3(3), 194-203. http://dx.doi.org/10.5539/jel.v3n3p194

Loima, J., \& Vibulphol, J. (2016). Learning and motivation in Thailand: A comparative regional study on basic education ninth graders. International Education Studies, 9(1), 31-43. http://dx.doi.org/10.5539/ies. v9n1p31

Mehrgan, K. (2013). Teaching Strategies in Second Language Acquisition. United States of America Research Journal (USARJ),1(3), 32-35.

Niemiec, C. P., \&t Ryan, R. M. (2009). Autonomy, competence, and relatedness in the classroom: Applying self-determination theory to educational practice. Theory and Research in Education, 7(2),133-144. http:// dx.doi.org/10.1177/1477878509104318

Papi, M., \&t Abdollahzadeh, E. (2011). Teacher motivational practice, student motivation, and possible L2 selves: An examination in the Iranian EFL Context. Language Learning, 62(2), 571-594. http://dx.doi. org/10.1111/j.1467-9922.2011.00632.x

Reeve, J. (2009). Why teachers adopt a controlling motivating style toward students and how they can become more autonomy supportive. Educational Psychologist, 44(3), 159-175. http://dx.doi. org/10.1080/00461520903028990

Schunk, D. (2000). Learning theories: An educational Perspective.(2nd ed). New Jersey: Prentice-Hall, Inc.

Struyven, K., Dochy, F., \& Janssens, S. (2003). Students' perceptions about new modes of assessment: A review. In M. Segers, F. Dochy, \& E. Cascallar (Eds.), Optimising new modes of assessment: In search of qualities and standards (pp. 171-223). Boston: Kluwer

Taka囚, V. P. (2008). Vocabulary learning strategies and foreign language acquisition (Vol. 27). Multilingual matters.

Tynjälä, P. (1997). Developing education students' conceptions of the learning process in different learning environments. Learning and Instruction, 7(3), 277-292. 